ФГБОУ ВПО «МГСУ»

ЗАВИСИМОСТЬ

ТЕПЛОПОТРЕБЛЕНИЯ

ОТ ДИНАМИКИ ТЕМПЕРАТУРЫ НАРУЖНОГО ВОЗДУХА В ПЕРИОД РЕЗКОГО ПОХОЛОДАНИЯ

Показана зависимость фактического теплопотребления здания от динамики температуры наружного воздуха в период резкого похолодания. Анализ этих данных важен в период максимальной нагрузки на систему отопления для регулирования работы систем, обеспечивающих требуемый микроклимат в помещениях. Показано, что солнечная радиация меняет теплопотребление здания, а использование даже небольших потоков теплоты снижает напряженность периода резкого похолодания для тепловой защиты здания и инженерных систем, способствует энергосбережению.

Ключевые слова: температура наружного воздуха, период резкого похолодания, теплота, солнечная радиация, теплопотребление здания.

\section{THE DEPENDENCE OF HEAT CONSUMPTION ON THE DYNAMICS OF EXTERNAL AIR TEMPERATURE DURING COLD SNAP PERIODS}

The dynamics of outdoor temperature variations during the cold period of the year influences the operation of the systems providing the required microclimate in the premises, which may be subject to automation systems that affects the IQ of a building, it is important to note that in the last decade there has been a growth in the participation of intelligent technologies in the formation of a microclimate of buildings. Studying the microclimate quality in terms of energy consumption of the premises and the building considers climate variability and outdoor air pollution, which is connected with the economic aspects of energy efficiency and productivity, and health of workers, as a short-term temperature fall in the premises has harmful consequences. Low outdoor temperatures dry the air in the premises that requires accounting for climate control equipment and, if necessary, the personal account of its work. Excess heat in the premises, including office equipment, corrects the temperature conditions, which reduces the adverse effect of cold snap.

Key words: external air temperature, cold snap period, heat, solar radiation, building thermal input.
Известно, что в холодный период года есть периоды резкого похолодания, когда после медленного понижения температуры в течение $10 \ldots 15$ дней, она затем резко снижается до минимума, после чего повышается и начинается потепление. В то же время периоды резкого похолодания часто характеризуются безоблачным небом и ярким солнцем, что приводит к теплопоступлению от солнечной радиации в помещения и увеличивает температуру наружных поверхностей ограждений здания.

Исследования периода резкого похолодания проводились профессором В.Н. Богословским в середине XX в., однако выделить влияние теплоты от солнечной радиации в температуре наружного воздуха не представлялось возможным ввиду ее относительной малости, да и не было признано необходимым. При этом период резкого похолодания оказывает влияние и на микроклимат помещений и теплопотребление здания, что связано также с отставанием в учете современного влияния изменяющегося климата на теплопотребление зданий [1].

Проведен мониторинг температуры наружного воздуха с 28 января по 4 февраля 2014 г. в период резкого похолодания в г. Москве. Измере-
It is known that during the cold period of the year, there are cold snap periods, when after a slow decrease of temperature within $10 \ldots 15$ days it decreases sharply to a minimum, and then rises up and warming begins. At the same time, during cold snap, the sky is often cloudless and the sun is bright, which brings solar radiation heat to the room and increases the outside surface temperature of the walls.

Professor V.N. Bogoslovskiy studied cold snap period in the mid-twentieth century. However, he could not identify the influence of solar radiation heat on the outside surface temperature because of its relative smallness. Besides, that influence wasn't recognized necessary. Thus, cold snap influences the indoor climate and building thermal input, due to the underrun of the current impact of climate change on building thermal input [1].

The outdoor temperature was monitored from 28 January to 4 February 2014 during a cold snap in Moscow with the use of the instrument measuring thermal flux density and temperature MTF- 
ния проводились с применением измерителя плотности тепловых потоков и температуры ИТП-МГ4.03/Х(I) «ПОТОК». Точность измерений составила $\pm 0,2{ }^{\circ} \mathrm{C}$, периодичность - 5 мин. Измерения проводились у наружной поверхности наружной стены на уровне 4-го этажа шестиэтажного административного здания с ориентацией по сторонам света: между юговосточной и южной сторонами (затенения от других зданий отсутствовали). Большое количество измерений всегда создает трудности с их анализом, однако соответствует поставленной задаче изучения периода резкого похолодания из-за его скоротечности.

Результаты измерений приведены на рис. 1, где даны две линии: сплошная - результаты мониторинга температуры наружного воздуха с учетом действия теплоты от солнечной радиации и от других теплопоступлений; пунктирная линия, соединяющая минимальные значения температуры наружного воздуха, которая близка к линии температуры наружного воздуха без влияния теплоты от солнечной радиации, но с учетом потерь теплоты ограждающими конструкциями здания. Всегда сложно анализировать линии мониторинга температуры из-за массы случайных факторов, которые трудно предвидеть и осмыслить их присутствие.
MG4.03/10X(I) "POTOK". Measurement accuracy was $\pm 0.2{ }^{\circ} \mathrm{C}$, frequency $-5 \mathrm{~min}$. We measured the outer surface of the outer wall at the level of the 4th storey of a six storey administrative building orientated in the cardinal directions: between the Southeastern and Southern sides (there were no shadings from other buildubgs). A large number of measurements always create difficulties with their analysis, however, it meets the objective of studying cold snap period due to its speed. Fig. 1 shows the measurement results, where there are two lines: the solid line shows the monitoring of outdoor air temperature taking into account the effect of solar radiation heat and other heat gains; the broken line connects the minimum outside temperature, which is close to the line of the outside temperature without the influence of solar radiation heat, but taking into account heat losses of the walls. It is always difficult to analyze line temperature monitoring because of the large number of random factors that are difficult to anticipate and understand their presence.

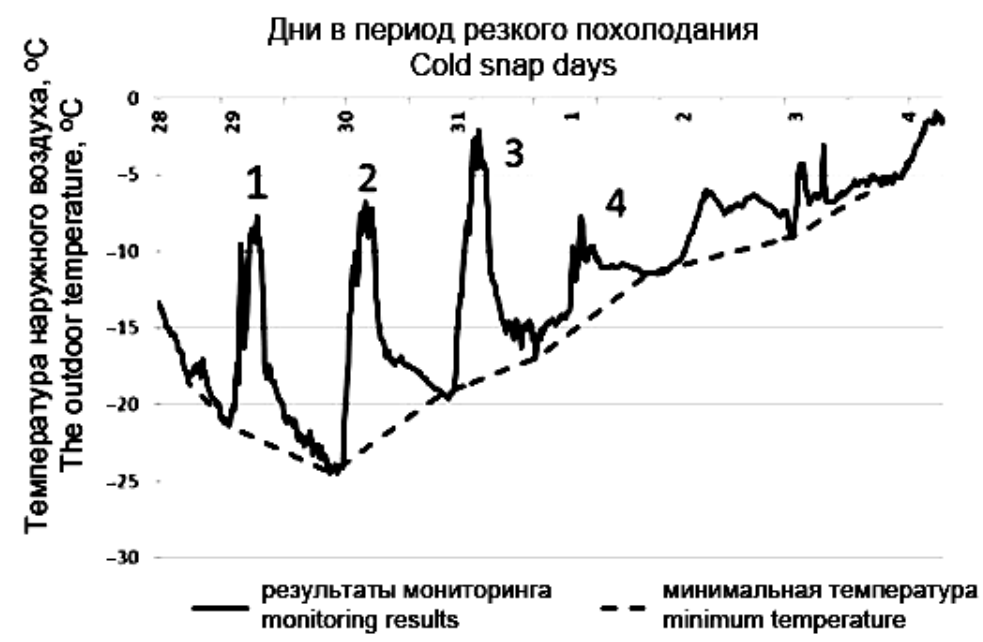

Рис. 1. Изменение температуры наружного воздуха в период резкого похолодания зимой 2014 г. в Москве с учетом действия солнечной радиации и теплопотерь через наружные ограждающие конструкции

На линии результатов мониторинга видны всплески температуры под номерами 1, 2 и 3 , сформированные под действием теплоты от солнечной радиации, а также потерь теплоты от наружной стены и расположенных ниже окна и кровли 2-этажной пристройки. На рис.
Fig. 1. The change of the outdoor temperature during cold snaps in winter 2014 in Moscow, taking into account the effect of solar radiation and heat loss through the enclosing part

Line monitoring results (1, 2 and 3) make visible the bursts of temperature, formed by solar radiation heat and heat loss from the outer wall and, located below, the window and the roof of a 2 storey building extension. Figure 1 shows that during the 1 st peak the temperature 
1 видно, как температура у поверхности стены здания поднялась для 1-го пика с -23 до $-7{ }^{\circ} \mathrm{C}$, для 2-го - c -24 до $-6{ }^{\circ} \mathrm{C}$, для 3-го - -20 до $-3{ }^{\circ} \mathrm{C}$. При этом интересно отметить, что всплески или пики температуры 1,2 и 3 на рис. 1 имеют неровный вид, что связано с изменением прозрачности атмосферы в связи с движением воздушных масс, водяного пара и вредных примесей от автотранспорта и других источников. С ночи 1 февраля резкое похолодание закончилось, появилась облачность, стало теплее и влияние солнечной радиации сократилось.

Амплитуда колебания температуры между дневным и ночным периодами суток находится в пределах от 14 до $16{ }^{\circ} \mathrm{C}$, что больше среднего значения для холодного периода года, равного $6{ }^{\circ} \mathrm{C}$. Такое колебание температуры наружного воздуха обусловлено поступлением теплоты от солнечной радиации, при которой разогревается поверхность стены и кровли, что вместе с теплопотерями от ограждающих конструкций дает приращение температуры наружного воздуха у наружной поверхности стены до $8 \ldots 10{ }^{\circ} \mathrm{C}$ в дневное время.

Потери теплоты за период измерений за счет теплопередачи через наружные стены с тепловой защитой по нормам СНиП II-3-79 «Строительная теплотехника» и нормам СНиП 23-02-2003 «Тепловая защита зданий» с коэффициентами теплопередачи 0,95 и 0,35 $\mathrm{BT} /\left(\mathrm{M}^{2} \cdot{ }^{\circ} \mathrm{C}\right)$ соответственно и при температуре внутреннего воздуха $20^{\circ} \mathrm{C}$ составили $38 \mathrm{BT} / \mathrm{M}^{2}$ и $14 \mathrm{BT} / \mathrm{M}^{2}$ при осреднении за рассматриваемый период, с учетом действия солнечной радиации и теплоты, поступающей в наружный воздух за счет теплопотерь. Теплопотери приводят к формированию восходящей струи относительно теплого воздуха у наружной поверхности стен и окон здания [2], а также от кровли, что сказывается на результатах мониторинга температуры наружного воздуха у поверхности наружной стены в сторону увеличения.

Теплопотери за период резкого похолодания от инфильтрации наружного воздуха в помещения через окна с сопротивлением инфильтрации по нормам СНиП II-3-79 и СНиП 2302-2003 с нормативной воздухопроницаемостью для окон жилых зданий 10 и 5 кг/( $\mathrm{M}^{2} \cdot$ ч) соответственно и при температуре внутреннего воздуха $20{ }^{\circ} \mathrm{C}$, составили $227 \mathrm{BT} / \mathrm{M}^{2}$ для 1-го этажа 12-этажного жилого здания и $56 \mathrm{BT} / \mathrm{m}^{2}$ в at the wall surface of the building went up from -23 to $-7{ }^{\circ} \mathrm{C}$, during the 2 nd peak - from -24 to $-6{ }^{\circ} \mathrm{C}$, during the $3 \mathrm{rd}$ peak - from -20 to $-3{ }^{\circ} \mathrm{C}$. It is interesting to note that the temperature peaks or perturbations 1,2 and 3 in Fig. 1 are not smooth due to the changes in the atmospheric transmittance connected with the movement of air masses, water vapor and contaminants from vehicles and other sources. Since the night of 1 February the cold snap was over, it was cloudy, the weather became warmer and the effect of solar radiation decreased.

The range of temperatures between day and night varies from 14 to $16{ }^{\circ} \mathrm{C}$, which is higher than the average temperature in the cold period of the year, equal to $6{ }^{\circ} \mathrm{C}$. This outdoor temperature variation is due to the flow of solar radiation heat, which heats the wall and the roof surface, which, together with the heat from walling, gives outdoor temperature increment of $8 \ldots 10^{\circ} \mathrm{C}$ at the outer surface of the wall in the daytime.

Heat losses within the measurement period due to heat transfer through the outer walls with thermal protection according to Construction Norms and Regulations SNiP II-3-79 "Construction heat engineering" and Construction Norms and Regulations SNiP 23-02-2003 "Building heat protection" with heat-transfer coefficients of 0.95 and $0.35 \mathrm{~W} /\left(\mathrm{m}^{2} \cdot{ }^{\circ} \mathrm{C}\right)$, respectively, and at the inside air temperature of $20{ }^{\circ} \mathrm{C}$ was $38 \mathrm{~W} / \mathrm{m}^{2}$ and $14 \mathrm{~W} / \mathrm{m}^{2}$ at averaging during the period under examination, taking into account the effect of solar radiation and heat coming to outdoor air due to heat loss. Heat losses form the upward current of relatively warm air at the outer walls surface and windows of the building [2], as well as from the roof, which increases the results of monitoring the outside air temperature at the outer wall surface.

Heat loss during cold snap period from infiltration of outdoor air into the room through a window with infiltration resistance according to Construction Norms and Rules II-3-79 and Construction Norms and Rules 23-02-2003 with standard air permeability for windows of residential buildings 10 and $5 \mathrm{~kg} /\left(\mathrm{m}^{2} \cdot \mathrm{h}\right)$, respectively, and at the inside air temperature of $20{ }^{\circ} \mathrm{C}$, amounted to $227 \mathrm{~W} / \mathrm{m}^{2}$ for the 1 st storey of 12 -storey residential buildings and $56 \mathrm{~W} / \mathrm{m}^{2}$ at the average for a 12 -storey residential build- 
среднем для 12-этажного жилого здания для двух вариантов норм соответственно, с учетом действия солнечной радиации и потоков теплоты от теплопотерь.

На рис. 2 приведены совокупные теплопоступления у наружной поверхности стены от солнечной радиации и теплопотерь за рассматриваемый период, при этом среднее значение теплопоступлений равно $83,4 \mathrm{BT} / \mathrm{m}^{2}$. ing for two variants of the standards, respectively, considering the effect of solar radiation and heat loss currents.

Fig. 2 shows the total heat supplied at the outer wall surface from solar radiation and heat loss during the period under examination, the average value of heat gain equal to $83.4 \mathrm{~W} / \mathrm{m}^{2}$.

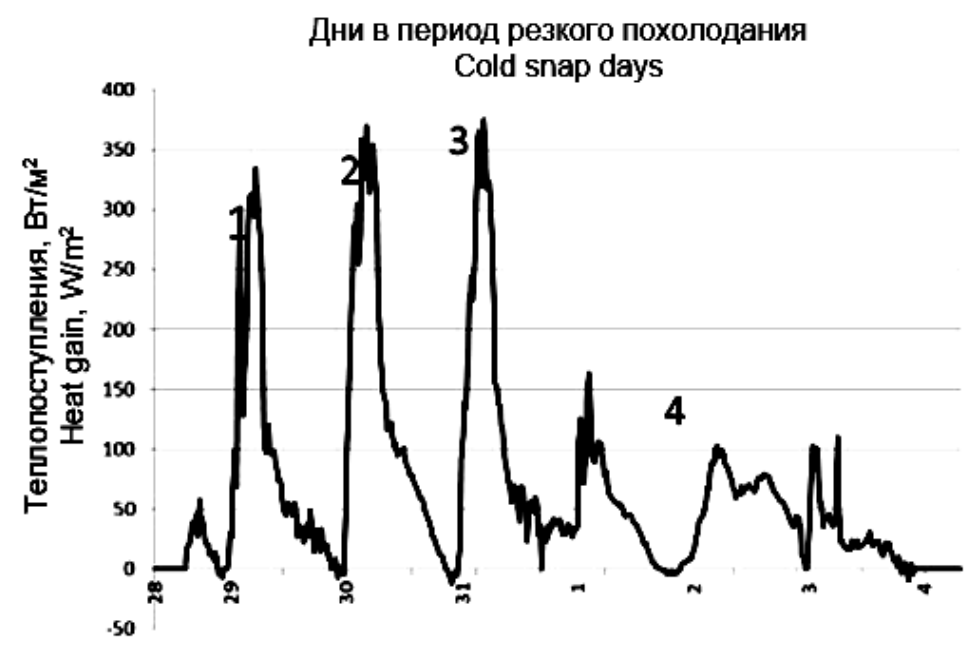

Рис. 2. Изменение совокупного теплопоступления от солнечной радиации и теплопотерь в период резкого похолодания зимой 2014 г. в Москве

При анализе рис. 2 видны три пика, изменение величины которых во времени составляет: 1-й пик - от 0 до $340 \mathrm{BT} / \mathrm{M}^{2}$, 2-й пик — от 0 до 360 $\mathrm{BT} / \mathrm{M}^{2}, 3$-й пик - от 0 до $370 \mathrm{BT} / \mathrm{m}^{2}$, что определяется перемещением солнца в течение светового дня. Несмотря на скоротечность пиков теплопоступлений от солнечной радиации, показанных на рис. 2, их влияние на параметры микроклимата, теплопотери помещений, теплопоступления от отопительных приборов в помещения присутствует. Инерционность наружных стен и скоротечность периода солнечной активности не позволяет теплоте от солнечной радиации проникнуть в толщу наружной стены [3] и существенно изменить температурный режим наружной стены. Однако снижение теплопотерь, особенно через наружные окна, в совокупности с теплопоступлением в помещения через окна от солнечной радиации влияют на температурный режим помещений в сторону увеличения температуры внутреннего воздуха и результирующей температуры [4]. Одновременно с временным потеплением от солнечной радиации и потерей теплоты у поверхности окон облучаемого фасада здания снижается величина гравитационного давления воздуха, влияющая на поступле-
Fig. 2. Variations of total solar radiation heat gain and heat loss during cold snaps in winter 2014 in Moscow

Fig. 2 shows 3 peaks, time variations of which are: the 1 st peak - from 0 to 340 $\mathrm{W} / \mathrm{m}^{2}$, the 2nd peak - from 0 to 360 $\mathrm{W} / \mathrm{m}^{2}$, the $3 \mathrm{rd}$ peak - from 0 to 370 $\mathrm{W} / \mathrm{m}^{2}$, which is determined by the sun movement during the day. Despite the speed of the peaks of the solar heat gains (Fig. 2) they influence the microclimate parameters, the heat loss of buildings, the heat gains from heating bodies in the premises. The inertia of the external walls and the speed of the solar activity period prevent the solar radiation heat from penetrating into the thickness of the outer wall [3] and change significantly the outer wall temperature. However, the reduction of heat loss, especially through the outer windows, together with solar radiation heat gain in the premises through a window increase the inside air temperature of the internal air and the resultant temperature [4]. Simultaneously with the temporary warming from solar radiation and heat loss at the window surface of the exposed building face reduces the value of the gravitational 
ние в помещения инфильтрационного воздуха при естественной системе вентиляции в здании, что снижает потери теплоты [5]. Данные поступления теплоты от прямой солнечной радиации на вертикальную поверхность при безоблачном небе приняты по [6]. pressure of the air affecting the infiltration air input to the premises by natural ventilation in the building, which reduces heat losses [5]. The data of direct solar radiation heat gain on a vertical surface under cloudless sky are taken according to [6].

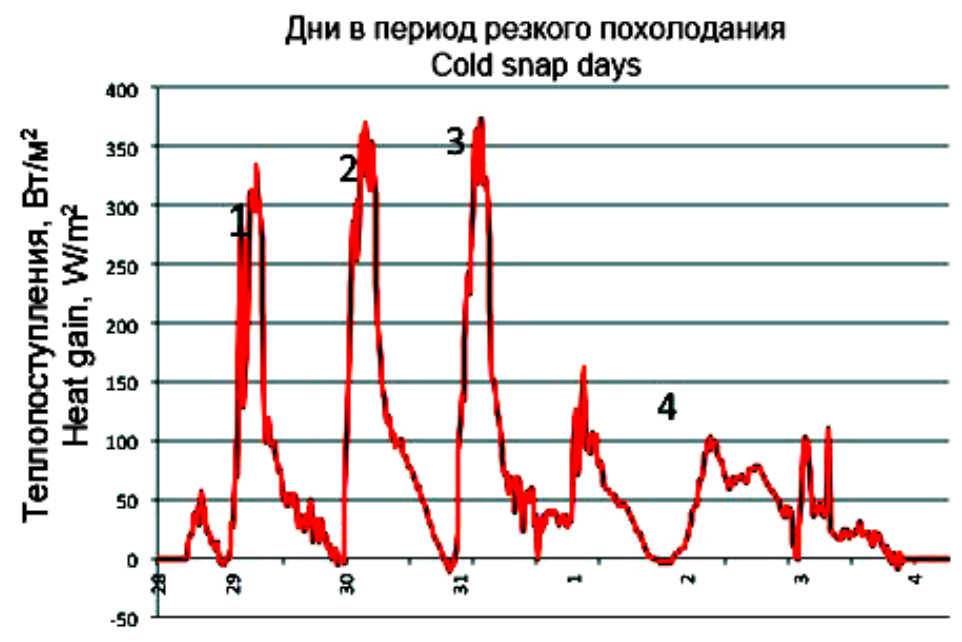

Рис. 3. Изменение совокупного теплопоступления от солнечной радиации и теплопотерь в период резкого похолодания зимой 2014 г. в Москве

Ориентировочный тепловой баланс теплового потока для пика 1 показанного на рис. 3 следующий:

$$
340 \mathrm{BT} / \mathrm{M}^{2}-\left(38 \mathrm{BT} / \mathrm{M}^{2}+171 \mathrm{BT} / \mathrm{M}^{2}+12 \mathrm{BT} / \mathrm{M}^{2}\right.
$$
$\left.+105 \mathrm{BT} / \mathrm{M}^{2}+15 \mathrm{BT} / \mathrm{M}^{2}\right)=0$,

где последовательно указана сумма тепловых потоков: от прямой и рассеянной солнечной радиации, теплопотери от стены, теплопотери от окна расположенного ниже, теплопотери от плоской кровли пристройки, отраженная теплота от солнечной радиации от кровли пристройки. Аналогичный тепловой баланс можно получить для всего рассмотренного периода резкого похолодания.

В инженерной практике применяется условная температура наружного воздуха, формирующаяся у поверхности наружных ограждающих конструкций здания под воздействием солнечной радиации в теплый период года, значение которой в холодный период года дополняется новыми факторами влияния, описанными выше.

Динамика изменения температуры наружного воздуха в холодный период года влияет на работу систем, обеспечивающих требуемый микроклимат в помещениях, работа которых может регулироваться системами автоматики, что оказывает влияние на коэффициент интеллекта здания [7], при этом важно отметить, что в последнее десятилетие имеет место рост участия интел-
Fig. 3. Variations of total solar radiation heat gain and heat loss during cold snaps in winter 2014 in Moscow

Fig. 3 shows the following approximate heat balance of heat current for peak 1 $340 \mathrm{~W} / \mathrm{m}^{2}-\left(38 \mathrm{~W} / \mathrm{m}^{2}+171 \mathrm{~W} / \mathrm{m}^{2}+\right.$ $\left.12 \mathrm{~W} / \mathrm{m}^{2}+105 \mathrm{~W} / \mathrm{m}^{2} 15 \mathrm{~W} / \mathrm{m}^{2}\right)=0$, where the amount of heat currents are sequentially: from direct and diffuse solar radiation, heat loss from the wall, the heat loss from the window below, the heat loss from the flat roof of the extension, the reflected heat from solar radiation from the roof of the extension. Similar heat balance can be obtained for all the cold snap period under examination.

Engineering practice use conventional outside air temperature, formed on the outer surface of the building envelope by solar radiation during the warm period of the year, the value of which during the cold period of the year, is supplemented by new factors described above.

The dynamics of outdoor temperature variations during the cold period of the year influence the operation of the systems providing the required microclimate in the premises, which may be subject to automation systems that affects the IQ of a building [7]. Here, it is important to note that the number of intelligent technologies in the 
лектуальных технологий в формировании микроклимата зданий [8].

Качество микроклимата с позиции энергопотребления помещением и зданием изучается с учетом переменчивости климата и загрязненности наружного воздуха, что связано с экономическими аспектами энергосбережения, производительностью труда и здоровьем работников [9], так как кратковременное понижение температуры в помещениях имеет вредные последствия. Низкие наружные температуры приводят к высушиванию воздуха в помещении, что требует учета при работе климатического оборудования и при необходимости организации персонального учета его работы $[10,11]$. Теплоизбытки в помещении, в т.ч. и от офисной техники, вносят корректировку в температурный режим помещения, что снижает неблагоприятное влияние периода резкого похолодания [12].

\section{БИБЛИОГРАФИЧЕСКИЙ СПИСОК}

1. Самарин О.Д. О подтверждении вероятностно-статистических соотношений между расчетными параметрами наружного климата // Известия высших учебных заведений. Строительство. 2014. № 3. С. 66-69.

2. Рыммаров А.Г., Смирнов В.В. Изменение коэффициента теплоотдачи на наружной поверхности ограждающих конструкций высотного здания в холодный период // Монтажные и специальные работы в строительстве. 2006. № 1. C. $26-28$.

3. Рыммаров А.Г., Лушин К.И. Особенности расчета теплового режима здания с массивными ограждающими конструкциями в холодный период года // Наука. Строительство. Образование. 2012. Вып. 2. Режим доступа: http://www.nso-journal.ru/public/journals/1/issues/ 2012/02/5.pdf. Дата обращения: 12.05.2014.

4. Рымаров А.Г., Самарин О.Д., Плотников A.A. Разработка научных основ управления параметрами внутреннего микроклимата на Большой спортивной арене стадиона «Лужники» // Энергосбережение и водоподготовка. 2000. № 2. C. 32-36.

5. Рымаров А.Г. Прогнозирование параметров воздушного, теплового, газового и влажностного режимов помещений здания // Academia. Архитектура и строительство. 2009. № 5. C. $362-364$.

6. Круглова А.И. Климат и ограждающие конструкции. М. : Стройиздат, 1970. 168 с.

7. Волков А.А. Интеллект зданий: формула // Промышленное и гражданское строительство. 2012. № 3. С. 54-57.

8. Самарин О.Д., Гришнева Е.А. Повышение энергоэффективности зданий на основе formation of a microclimate of buildings [8] in the last decade has been growing.

The study of the microclimate quality in the terms of energy consumption of the premises and building considers climate variability and outdoor air pollution, which is connected with the economic aspects of energy efficiency and productivity, and health of workers [9], as a short-term temperature fall in the premises has harmful consequences. Low outdoor temperatures dry the air in the premises that requires accounting for climate control equipment and, if necessary, the personal account of its work [10, 11]. Excess heat in the premises, including office equipment, corrects the temperature conditions, which reduces the adverse effect of cold snap [12].

\section{REFERENCES}

1. Samarin O.D. O podtverzhdenii veroyatnostnostatisticheskikh sootnosheniy mezhdu raschetnymi parametrami naruzhnogo klimata [The Probabilistic and Statistical Correlation Between the Calculated Parameters of Outdoor Climate]. Izvestiya vysshikh uchebnykh zavedeniy. Stroitel'stvo [News of Institutions of Higher Education. Construction]. 2014, no. 3, pp. 66-69.

2. Rymarov A.G., Smirnov V.V. Izmenenie koeffitsienta teplootdachi na naruzhnoy poverkhnosti ograzhdayushchikh konstruktsiy vysotnogo zdaniya $\mathrm{v}$ kholodnyy period [Variations of Heat Loss Coefficient on the Outer Surface of Multistoried Building Envelope in the Cold Period]. Montazhnye i spetsial'nye raboty $v$ stroitel'stve [Erecting and Special Works in Construction]. 2006, no. 1 , pp. $26-28$.

3. Rymarov A.G., Lushin K.I. Osobennosti rascheta teplovogo rezhima zdaniya s massivnymi ograzhdayushchimi konstruktsiyami v kholodnyy period goda [Heavy Envelope Buildings: Thermal Analysis for the Winter Season]]. Nauka. Stroitel'stvo. Obrazovanie [Science. Construction. Education]. 2012, no. 2. Available at: http://www.nsojournal.ru/public/journals/ 1/issues/2012/02/5.pdf. Date of access: 12.05.2014.

4. Rymarov A.G., Samarin O.D., Plotnikov A.A. Razrabotka nauchnykh osnov upravleniya parametrami vnutrennego mikroklimata na Bol'shoy Sportivnoy Arene stadiona «Luzhniki» [The Development of Scientific Basis of Managing Inside Microclimate Parameters at the Sport Arena on "Luzhniki" Stadium]. Energosberezhenie $i$ vodopodgotovka [Energy Saving and Water Conditioning]. 2000, no. 2, pp. 32-36.

5. Rymarov A.G. Prognozirovanie parametrov vozdushnogo, teplovogo, gazovogo i vlazhnostnogo rezhimov pomeshcheniy zdaniya [Prediction of the Parameters of Air, Heat, Gas and Humidity Balances in the Premises]. Academia. Arkhitektura i stroitel'stvo [Academia. Architecture and Construction]. 2009, no. 5, pp. 362-364.

6. Kruglova A.I. Klimat $i$ ograzhdayushchie konstruktsii [Climate and Building Envelope]. Moscow. Stroyizdat Publ., 1970, 168 p. 
интеллектуальных технологий // Энергосбережение и водоподготовка. 2011. № 5 (73). C. $12-14$.

9. Sakr W., Weschler C.J., Fanger P.O. The impact of sorption on perceived indoor air quality // Indoor Air. 2006. Vol. 16. No. 2. Pp. 98-110.

10. Wyon D.P., Fang L., Lagercrantz L., Fanger P.O. Experimental determination of the limiting criteria for human exposure to low winter humidity indoors (RP-1160) // HVAC\&R Research Journal. 2006. Vol. 12. No. 2. Pp. 201-213.

11. Kaczmarczyk J., Melikov A., Bolashikov Z., Nikolaev L. \& Fanger P.O. Human response to five designs of personalized ventilation // HVAC\&R Research Journal. 2006. Vol. 12. No. 2. Pp. 367-384.

12. Bakó-Biró Z., Wargocki P., Weschler C.J., Fanger P.O. Effects of pollution from personal computers on perceived air quality, SBS symptoms and productivity in offices // Indoor Air. 2004. Vol. 14. No. 3. Pp. 178-187.

Поступила в редакцию в июле 2014 г.

Об ав торах: Рымаров Андрей Георгиевич - кандидат технических наук, доцент кафедры отопления и вентиляции, Московский государственный строительный университет (ФГБОУ ВПО «МГСУ»), 129337, г. Москва, Ярославское шоссе, д. 26, rymarov@yandex.ru;

Ботнарь Максим Игоревич - ассистент кафедры теплотехники и теплогазоснабжения, Московский государственный строительный университет (ФГБОУ ВПО «МГСУ»), 129337, г. Москва, Ярославское шоссе, д. 26, botnarmi @gmail.com.
7. Volkov A.A. Intellekt zdaniy: formula [Intelligence of Buildings: Formula]. Promyshlennoe i grazhdanskoe stroitel'stvo [Industrial and Civil Engineering]. 2012, no. 3, pp. 54-57.

8. Samarin O.D., Grishneva E.A. Povyshenie energoeffektivnosti zdaniy na osnove intellektual'nykh tekhnologiy [Improving the Energy Efficiency of Buildings Through Intelligent Technologies]. Energosberezhenie $i$ vodopodgotovka [Energy Saving and Water Conditioning]. 2011, no. 5 (73), pp. 12-14.

9. Sakr W., Weschler C.J., Fanger P.O. The Impact of Sorption on Perceived Indoor Air Quality. Indoor Air. 2006, vol. 16, no. 2 , pp. $98-110$.

10. Wyon D.P., Fang L., Lagercrantz L., Fanger P.O. Experimental Determination of the Limiting Criteria for Human Exposure to Low Winter Humidity Indoors (RP-1160). HVAC\&R Research Journal. 2006, vol. 12, no. 2, pp. 201-213. DOI: http://dx.doi.org/10.1080/ 10789669.2006.10391175.

11. Kaczmarczyk J., Melikov A., Bolashikov Z., Nikolaev L., Fanger P.O. Human Response to Five Designs of Personalized Ventilation. HVAC\&R Research Journal. 2006, vol. 12, no. 2, pp. 367384. DOI: http://dx.doi.org/10.1080/10789669.2006.10391184.

12. Bakó-Biró Z., Wargocki P., Weschler C.J., Fanger P.O. Effects of Pollution from Personal Computers on Perceived Air Quality, SBS Symptoms and Productivity in Offices. Indoor Air. 2004, vol. 14, no. 3, pp. 178-187.

Received in July 2014.

About the authors: Rymarov Andrey Georgievich Candidate of Technical Sciences, Associate Professor, Department of Heating and Ventilation, Moscow State University of Civil Engineering (MGSU), 26 Yaroslavskoe shosse, Moscow, 129337, Russian Federation; rymarov@yandex.ru;

Botnar' Maksim Igorevich - Assistant Lecturer, Department of Thermal engineering and Heat and Gas Supply, Moscow State University of Civil Engineering (MGSU), 26 Yaroslavskoe shosse, Moscow, 129337, Russian Federation; botnarmi@gmail.com.

\section{Для цитирования:}

Рымаров А.Г., Ботнарь М.И. Зависимость теплопотребления от динамики температуры наружного воздуха в период резкого похолодания // Строительство: наука и образование. 2014. № 3. Ст. 4. Режим доступа: http://www.nso-journal.ru.

For citation:

Rymarov A.G., Botnar' M.I. Zavisimost' teplopotrebleniya ot dinamiki temperatury naruzhnogo vozdukha v period rezkogo pokholodaniya [The Dependence of Heat Consumption on the Dynamics of External Air Temperature During Cold Snap Periods]. Stroitel'stvo: nauka i obrazovanie. [Construction: Science and Education]. 2014, no. 3, paper 4. Available at: http://www.nsojournal.ru. 